\title{
Is Applied Ethics Morally Problematic?
}

\author{
David J. Franz ${ }^{1,2}$ iD
}

Accepted: 25 April 2021 /Published online: 30 April 2021

(C) The Author(s) 2021

\begin{abstract}
This paper argues that applied ethics can itself be morally problematic. As illustrated by the case of Peter Singer's criticism of social practice, morally loaded communication by applied ethicists can lead to protests, backlashes, and aggression. By reviewing the psychological literature on self-image, collective identity, and motivated reasoning three categories of morally problematic consequences of ethical criticism by applied ethicists are identified: serious psychological discomfort, moral backfiring, and hostile conflict. The most worrisome is moral backfiring: psychological research suggests that ethical criticism of people's central moral convictions can reinforce exactly those attitudes. Therefore, applied ethicists unintentionally can contribute to a consolidation of precisely those social circumstances that they condemn to be unethical. Furthermore, I argue that the normative concerns raised in this paper are not dependent on the commitment to one specific paradigm in moral philosophy. Utilitarianism, Aristotelian virtue ethics, and Rawlsian contractarianism all provide sound reasons to take morally problematic consequences of ethical criticism seriously. Only the case of deontological ethics is less clear-cut. Finally, I point out that the issues raised in this paper provide an excellent opportunity for further interdisciplinary collaboration between applied ethics and social sciences. I also propose strategies for communicating ethics effectively.
\end{abstract}

Keywords Applied ethics · Motivated reasoning · Peter Singer - Interdisciplinary moral philosophy $\cdot$ Consequences of ethical criticism $\cdot$ Moral reasoning

As one of the most prominent moral philosophers of the twentieth century, Peter Singer has had an impact on people well beyond academic discussions. On the one hand, Singer's philosophy has certainly inspired many people to question their attitudes about the moral status of animals and to reflect on their own behaviour toward animals. The subtitle of Singer's Animal Liberation 'The Definitive Classic of the Animal Movement' (Singer, 2009) nicely expresses this positive societal impact of Singer's thinking. On the other hand, especially Singer's extreme theses about the moral acceptability of abortion and euthanasia (Singer, 2011) have oftentimes lead to conflict and hostility. As Singer himself points out, he had

David J. Franz

david.franz@uni-wuerzburg.de

1 Department of Philosophy, University of Wuerzburg, Wuerzburg, Germany

2 Department of Psychology, University of Wuerzburg, Wuerzburg, Germany 
to face hostile protests against his philosophy and his person on several occasions (Singer, 1993). Activists tried-sometimes successfully—to get academic events cancelled Singer was supposed to attend. People with disabilities accused him of denying their right to life and compared his philosophy to Nazi ideology several times. In at least one instance, Singer even was physically attacked.

This introductory example illustrates an important aspect of applied ethics: Applied ethics itself is a form of societal communication and, therefore, can lead to potentially morally problematic consequences. Applied ethicists not only want to explore the ethically right stance on hotly disputed normative topics, such as euthanasia, abortion, the moral status of animals, etc. They also want to have an impact on society (Birnbacher, 1999, 2016). When a philosopher working in applied ethics argues for a specific ethical position on, for example, the question of the permissibility of euthanasia, she-sometimes implicitly, sometimes explicitly-also argues that society should adopt her stance. Accordingly, applied ethicists frequently take part in social discussions or work in societal institutions dealing with ethical topics, such as ethics committees.

In this paper, I want to explore why applied ethics itself can be morally problematic (for other positions problematizing the ethical value of ethics see Batson, 2016; Luhmann, 2008). At first, I draw on psychological research on identity and reasoning in order to understand why morally loaded communication-i.e., judging people or behaviour from an ethical point of view-can have unwanted consequences. Subsequently, I identify three possible consequences of morally loaded communication by applied ethicists, which are morally problematic. After that, I argue that moral philosophers of different ethical traditions have sound reasons to take the concerns of this paper seriously. Next, I flesh out one main consequence of my argumentation: the importance of in-depth interdisciplinary research on morally problematic consequences of applied ethics. Finally, I propose a few communication strategies that can be used by applied ethicists to mitigate potential backlashes of their ethical critique.

\section{Why Arguments Can Backfire}

A good starting point for understanding why morally loaded communication can lead to ethically unwanted consequences is the fundamental motivation that shapes many people's perception of themselves and their surroundings. "The motivational principle of valuing "me and mine" means that we are motivated to see ourselves and anything or anyone connected to us, such as our families, teams, nations, or even possessions, in a positive light.' (Smith et al., 2015, 17) People want themselves to appear as intelligent, ethical, and competent, and they want their important peer-groups to be intelligent, ethical, and competent. To maintain this idealized picture of one's identity, people oftentimes evaluate themselves, their in-group, as well as information about themselves and their in-group in a highly biased manner.

The main reason why ethical criticism by applied ethicists can be morally problematic is that it rarely questions only singular normative convictions of people. In many cases, ethical criticism problematizes people's identities and worldviews. Take for example Singer's arguments for a vegetarian lifestyle (Singer, 2009, 2011). These arguments not only question people's eating habits. They also problematize people's individual identity (e.g., "I am a decent and animal-loving human being"), their collective feelings of belonging (e.g., "It is perfectly normal that my family and friends are barbecuing every Sunday"), and their 
general cultural views (e.g., "Eating meat is a central part of the American way of life."). Being confronted with arguments that call one's social world into question is a highly unpleasant experience. It is psychologically much harder to change one's individual and collective identity than to protect one's existing belief system. For this reason, ethical criticism can trigger various psychological defence mechanisms, which can result in people adhering to their initial beliefs even stronger than before. Consequently, morally loaded communication has the potential to strengthen exactly those attitudes and behaviours that it criticizes.

In order to buttress further this brief argumentative sketch, I will draw on psychological research on individual and collective identity in the following section. After that, I will explain various psychological defence mechanisms people engage in to protect their worldview. This will help in understanding possible drawbacks of applied ethics.

\section{Building Up a Positive Identity}

People's urge for a positive individual and collective identity is so strong that it leads to several biases. As suggested by research on the above-average effect, in a lot of different realms, people believe to have higher skills than the average person has (Dunning et al., 2004; Heine \& Hamamura, 2007; Pronin et al., 2004; Sedikides et al., 2005; Zell et al., 2020). For example, by believing to be better than average in driving responsibly (Svenson, 1981), in handling guns safely (Stark \& Sachau, 2016), or in being friendly, conscientious, or honest (Brown, 2012), people inflate their individual self-image. Many people also believe themselves to be less suggestible by media communication than others are, as illustrated by the third-person effect (Andsager \& White, 2013; Eisend, 2017; Paul et al., 2000; Sun et al., 2008). People think of themselves as less easily affected than other people by undesirable media influences, such as the impact of "fake news" on political attitudes (Jang \& Kim, 2018), the effect of marketing techniques on purchasing behaviour (Xie \& Johnson, 2015), or the influence of sexual content on one's own sexuality (Rosenthal et al., 2018; Shen et al., 2015). By believing to be more skilful and less suggestible than others are, people build up their positive self-image. Furthermore, both effects suggest that people show overconfidence because it is highly unlikely that the average research participant actually is more skilled and less suggestible than the average person is.

People's urge for a positive collective identity translates into a robust in-group bias (Aberson et al., 2000; Rubin \& Hewstone, 1998; Mullen et al., 1992; Buhl, 1999; Bettencourt et al., 2001). People rate members of their own group (e.g., political party, religion, nation, ethnic group, etc.) more positively, for example, as more intelligent, talented, likeable, diligent, or competent than members of other groups. People are also more likely to cooperate with members of their own group, especially in cases, in which this cooperation comes along with personal costs (Balliet et al., 2014).

\section{Preserving a Positive Identity}

People tend to react strongly to threats to their individual and collective self-esteem (Gaertner et al., 2002). Encountering information that questions one's fundamental convictions-and, thereby, one's individual and collective identity — creates a state of psychological discomfort (Cooper, 2007; Festinger, 1957). People are highly motivated to resolve this unpleasant state or to avoid it altogether. For this reason, they engage in various psychological defence mechanisms. 
For example, people are very good at explaining away evidence that questions their positive view about their own skills. As research on the self-serving attributional bias suggests, people tend to interpret information about themselves in a self-serving manner (Campbell \& Sedikides, 1999; Mezulis et al., 2004; van Dellen et al., 2011). When people are confronted with negative feedback about their skills, they identify the reasons for this feedback in external factors, such as bad luck, unfavourable situational circumstances, or other people's behaviour. In contrast, in light of positive feedback, people see the reasons for this feedback in internal factors, such as their own skills, effort, or dispositions. In short, people take full credit for their successes but take only partial responsibility for their fails.

There is also considerable evidence for people's willingness to protect their positive image of their in-group. Research suggests that people are more willing to punish outgroup members for criticism of their group than to punish in-group members for the same criticism (Thürmer \& McCrea, 2018). They likewise evaluate criticism of their in-group as less threatening and as more constructive when the critic is a member of their in-group than when she is from the out-group (Thürmer \& McCrea, 2018). Democrats and Republicans equally rate information more positively (e.g., as more reliable, correct, etc.) that supports their own party's position than conflicting information (Ditto et al., 2019). Furthermore, if people see other groups as a threat to the sacred values of their in-group or as a threat to resources valued by their in-group, prejudice against out-groups is amplified (Aberson, 2019; Riek et al., 2006).

The examples outlined so far can be interpreted as cases of motivated reasoning (Kunda, 1990; Nickerson, 1998). People's reasoning processes and their evaluation of arguments are highly driven by their motivation to protect their basic worldviews and their identity. It is important to note that, in many cases, people do not recognize this influence of fundamental motivations on their reasoning processes. They simply believe to be evaluating arguments on a rational basis (Hornsey \& Fielding, 2017; Lewandowsky et al., 2016). In the remainder of this section, I want to illustrate two particularly illuminating cases of motivated reasoning that help to understand the possible drawbacks of morally loaded communication.

A particularly unambiguous example of motivated reasoning is the motivated rejection of science or of facts in general. Concerning many different controversial topics, such as manmade climate change, the death penalty, or the influence of violent video games on aggression, people interpret information and arguments in a way that is consistent with their identities and fundamental convictions. They judge that evidence and experts to be reliable that buttress their own stance, while simultaneously criticizing contrary evidence and experts with opposing views heavily (Ditto et al., 2019; Greitemeyer, 2014; Kahan et al., 2011; Lord et al., 1979; Nauroth et al., 2014, 2015). People also selectively give more weight to specific information that fits their worldview than to counter-information (Kahan et al., 2009). Beyond that, people's memory can also be distorted in a manner that makes people's recollection of information and events consistent with their basic worldview (Hennes et al., 2016; Shao \& Goidel, 2016). People remember information that is in accordance with their convictions and forget contrary information. Finally, of special interest for the argumentation of this paper are studies suggesting that educating people about the falsehood of their convictions can backfire. Since people are highly motivated to arrive at conclusions that fit their basic worldview, confronting them with counter-evidence can sometimes have the consequence that they stick 
to their worldview even stronger than before (Greitemeyer, 2014; Hart \& Nisbet, 2012; Lord et al., 1979; Nyhan et al., 2014). Furthermore, this can even come along with serious direct ethical consequences. For example, mentioning climate change as a cause of a famine catastrophe can reduce the willingness to help the victims in climate sceptics (Chapman \& Lickel, 2016).

My second example for motivated reasoning is the way many people in western societies justify their consumption of meat. From a psychological perspective, meat consumption comes along with a basic cognitive conflict. One the one hand, most people believe that harming animals without sufficient reasons is morally wrong. On the other hand, the same people know that, especially in factory farming, animals are seriously harmed. Acknowledging that animals are harmed for one's own gustatory pleasure could have a detrimental impact on one's picture of oneself as a decent human being. There is considerable psychological evidence suggesting that people resolve this conflict by motivated reasoning processes (Bastian \& Loughnan, 2017; Loughnan et al., 2014; Plous, 1993).

There are several strategies people deploy to resolve the conflict implicated by their meat consumption in favour of their positive identity (Piazza et al., 2015; Rothgerber, 2013, 2014): They simply avoid thinking about animal suffering in factory farming, they claim to consume only small quantities of meat, or they even doubt that animals are being harmed for meat production at all. Another strategy is to believe that eating meat is simply unavoidable if one wants to avoid risking serious health problems. There is also evidence suggesting that meat eaters devalue vegetarians (e.g., through stereotyped and prejudiced descriptions) in order to assure themselves that their own eating habits are unproblematic (Bastian \& Loughnan, 2017). Finally, several studies suggest that meat eaters believe that specifically those animals that are used as food in their culture have only a diminished capacity to experience mental states, such as pain, happiness, sadness, suffering, etc. (Bastian et al., 2012; Bilewicz et al., 2011; Bratanova et al., 2011; Loughnan et al., 2010; Ruby \& Heine, 2012).

Because meat consumption is a highly controversial topic, I want to stress that the outlined points are not to be confused with a normative defence of vegetarianism. Rather, I want to emphasize the fact that psychological research on justifications of meat consumption suggests that many people's meat-related attitudes are the result of their eating behaviour (Bastian \& Loughnan, 2017; Timm, 2016). While people claim to believe in the ethical justifiability of meat consumption because of the reasons they cite, research suggests that it is oftentimes the other way round. People engage in the outlined defence strategies (e.g., ignoring the negative consequences of meat consumption, devaluing vegetarians, believing that edible animals have more limited mental experiences than inedible animals, etc.) because they eat meat (Bastian \& Loughnan, 2017; Timm, 2016). Consequently, an applied ethicist arguing for vegetarianism can be confronted with the challenges that, firstly, people are highly motivated to reject arguments for vegetarianism because of their urge to protect their positive identity, and, secondly, people do not realize this influence on their reasoning processes. This makes it likely that the ethicist achieves the exact opposite of what she aims at. After being confronted with the ethical arguments for vegetarianism, meat eaters might engage in the outlined defence strategies and, thereby, become even more convinced of the justifiability of their eating behaviour than before. From the stance of a pro-vegetarian philosopher, this is a morally problematic consequence of her own morally loaded communication (see next section for more details on this phenomenon of moral backfiring). 


\section{The Problematic Side of Applied Ethics}

To outline possible morally problematic consequences of applied ethics, I will draw on the fictitious example of a very religious woman whose religious convictions are grounded on the belief that human life is sacred under all circumstances. This women is confronted with Singer's criticism of the doctrine of the sanctity of human life and his arguments for the permissibility of abortion and euthanasia (Singer, 2011).

If one analyses this case with the outlined psychological mechanisms in mind, it becomes evident that Singer's philosophy does not simply question singular ethical convictions of the women (e.g., "Human life is sacred, no matter what"). Rather, it problematizes central parts of her identity. From a psychological point of view, Singer tells this woman that her religious normative believe system is fundamentally flawed, and thereby, that her self-image is excessively positive. While she believes to live in accordance with divine moral standards, Singer tells her that these standards are a mere delusion and that she is not the ethical person she thinks she is. Beyond that, he also tells her that her most important in-group is not the morally respectable religious community she thinks it is. Consequently, the woman's complete social world is at stake when she is confronted with Singer's moral philosophy.

I do not want to imply that Singer's moral stances are right and the women's believes are wrong (or the other way round). Rather, I want to use the extreme gap between Singer's philosophical stance and the woman's believe system to illustrate three morally problematic consequences of morally loaded communication by applied ethicists.

1) Serious psychological discomfort. Questioning people's individual and collective identity from an ethical point of view can be morally problematic, simply because it is highly unpleasant for those people. It can be a drastic and burdensome event for the woman to be told by Singer that, from the viewpoint of his preference utilitarianism, her selfimage is, at least in parts, a self-delusion and that the in-group she values is not that valuable at all. Beyond that, it is vital to note that viewing oneself in a positive light can be an important factor that keeps one mentally healthy (Mezulis et al., 2004; Sowislo \& Orth, 2013; Zell et al., 2020). Therefore, if the woman struggles with mental health problems or even suffers from clinical disorders, such as depression, questioning her social universe might contribute to a worsening of her mental health.

Against these concerns, one might point out that the majority of people does not suffer from serious mental health problems. Moreover, the applied ethicist might argue that in many cases the moral offences she criticizes weigh more heavily than the possible distress she causes with her ethical critique. I admit that this might sometimes hold true. However, from this argument it does not follow that it is always justified simply to assume that ethical criticism is ethically more important than the distress it can cause. Therefore, applied ethicists should carefully reflect upon the possible impact of their ethical criticism on the mental condition of the people in their target group. It is important to note that this task can only be accomplished by drawing on empirical knowledge, which makes applied ethics fundamentally interdisciplinary (Birnbacher, 1999, 2016).

2) Moral backfiring. The most important argument for the moral questionability of applied ethics is that, in some instances, morally loaded communication can cause the exact opposite of what is intended by the applied ethicist. As pointed out above, when con- 
fronted with counter-attitudinal evidence, people engage in motivated reasoning to protect their worldviews and identities, which can in some cases result in a bolstering of those attitudes that have been called into question. When the woman in my example is confronted with Singer's philosophy, she will automatically start searching for reasons to believe that Singer's theses are untenable. Her moral outrage will be enormous and she will find many reasons that justify her revulsion. Perhaps, she will even start to question the personal integrity of Peter Singer. In the end, she will be even more convinced about the sanctity of human life and the wrongfulness of abortion and euthanasia than before. Thus, in this exemplary case, Singer's standing up for his ethical position leads to the exact opposite of what he has intended. If one is convinced that categorically prohibiting euthanasia and abortion is ethically wrong, just as Singer is, then it surely is morally questionable to amplify people's beliefs in the wrongness of abortion and euthanasia. Ironically, Singers own philosophy has the potential of doing exactly that. The fact that ethical communication can lead to moral backfiring should be a point worth considering for all philosophers working in applied ethics because this phenomenon can undermine the central concern of applied ethicists. Applied ethicists unintentionally can contribute to a consolidation of precisely those social circumstances that they condemn to be unethical.

3) Hostile conflict. In the worst-case scenario, morally loaded communication can even contribute to morally problematic clashes. Questioning moral worldviews can lead to hate, aggression, and even violence. The woman being challenged by Singer's philosophy might not only engage in motivated reasoning, she might also take more extreme actions against liberal stances on abortion and euthanasia. Together with her peers from her religious community, she might start protesting publicly against Singer and demand a limitation of Singer's right to advocate his position in public. She might even attend one of Singer's lectures and attack him physically. As outlined by Singer himself, both things have actually happened to him (Singer, 1993). ${ }^{1}$ In an extreme case, the woman might even take part in violent attacks against abortion clinics.

I do not want to claim that ethical criticism of certain social practices by moral philosophers is the sole cause of aggressive and violent backlashes. However, the aforementioned psychological research suggests that morally loaded communication by applied ethicists can contribute to such incidents. I suspect that most applied ethicists would judge fuelling violent conflicts to be unethical. Consequently, reflection on the possibility of such extreme consequences should be a mandatory part of the applied ethicist's work.

The arguments I brought forward are not supposed to be an attack on applied ethicists. I do not want to urge them to stop communicating their ethical positions publicly. However, I think that applied ethicists should take the problems outlined above as serious. The fundamental philosophical question to be answered here is: Is there a universal moral obligation to communicate the ethical stances of applied ethics under all circumstances? As might be obvious through the points I made above, I would answer this question in the negative.

\footnotetext{
1 It is also telling that Singer and two of his colleagues have recently launched a new journal solely devoted to highly controversial topics. The journal provides authors the opportunity to publish their arguments under a pseudonym, in order to protect them "from threats to their careers or physical safety" (https://journalofcontroversialideas.org/). Apparently, some applied ethicists have been confronted with morally problematic consequences of applied ethics to such an extent that they do not feel safe anymore in their philosophical work. This disturbing trend further speaks for the urgency of the points I raise in this paper.
} 
Admittedly, it is very difficult to specify under which circumstances exactly morally loaded communication by applied ethics is itself morally wrong. An intuitive answer would be that it must be very likely that the ethicist's communication leads to morally problematic consequences. This line of reasoning again points to the fundamentally interdisciplinary character of applied ethics: An ethical judgement about the consequences of morally loaded communication is only possible if one is empirically informed about the extent and probability of these consequences and about possibilities of counteracting them (see the section after next).

\section{A Problem For Different Ethical Paradigms}

It is important to note that the arguments I outlined in the previous sections are not dependent on a specific ethical stance. Many applied ethicists following different lines of ethical argumentation have reasons to reflect on the morally problematic consequences of their ethical criticism. However, because there is a myriad of different positions and theories in applied ethics, it is not possible to show how my worries are relevant for each theory in applied ethics. Nevertheless, many theories in applied ethics are highly influenced by the most prominent paradigms in moral philosophy. For this reason, it suffices to show that utilitarianism, virtue ethics, and Rawls's theory of justice all provide good reasons for applied ethicists to be concerned with the moral significance of their own communication. Therefore, all moral philosophers whose arguments in applied ethics are inspired by at least one of these ethical paradigms have reasons to take into account the problems I pointed out. Only deontological ethics, at least in some versions, might remain unconcerned by the arguments I brought forward.

Utilitarianism: Utilitarian ethics is fundamentally consequentialist (e.g., Mill, 1998/1871; Singer, 2009, 2011). According to utilitarian thinking, an action is morally right if it leads to morally good consequences, or in other words, if it maximizes overall utility. This extreme short characterization of utilitarian theories is already enough to show that utilitarians should be concerned with the points I made. My whole argumentation focuses mainly on consequences and is therefore close to utilitarian thinking. Thus, it would only be consistent if utilitarians applied their way of ethical reasoning to their own ethical arguments and theories. For example, one could theorize about the utility of Singer's preference utilitarianism. How much has Singer's philosophy itself increased moral utility in the world and how much has it led to consequences that decreased utility? Depending on the answer to that question, further interesting questions can arise. Suppose for the moment that one could show that Singer's philosophy actually has had more negative than positive consequences and decreased the overall utility in the world. Does Singer now have to give up some of his extreme positions, because giving them up would maximize the utility caused by his own theory? Or should he at least be much more careful advocating his stance publicly? Trying to answer such questions goes far beyond the scope of this article. However, it should be clear that reflecting on morally problematic consequences of applied ethics follows naturally from a utilitarian stance.

Virtue ethics. Aristotle famously argued in his Nicomachean Ethics that being truly virtuous means being disposed to act in a virtuous manner under many different circumstances (Aristotle, 2009). The virtuous person acts out of a deep-seated habit that she has formed in many years of moral education and training. Furthermore, a truly virtuous person always recognizes what is morally at stake in a specific situation. She has the 
intellectual capacity to grasp the morally relevant aspects of a situation and to determine the appropriate way of acting under particular circumstances. Therefore, Aristotelian virtuousness is a combination of dispositions to act rightly and an ability to adequately understand and interpret situational circumstances. Beyond that, according to Aristotle, a virtue lies in the middle of two extremes. A truly virtuous person is capable of striking a balance between two extreme ways of acting. For example, the virtue of fortitude is in the middle between the two vices cowardice and foolhardiness. Being truly brave means that one does neither flee cowardly in light of danger nor approach the threat carelessly.

It is highly plausible to conclude from this short characterization of Aristotelian virtuousness that the virtuous person should also know the middle concerning morally loaded communication. A virtuous person should be able to realize under what circumstances it is appropriate to voice ethical concerns and in which cases it might be better to remain silent. From the point of view of virtue ethics, one might argue that being a virtuous applied ethicist means to be in the middle between merciless moralization and detached amorality. Hence, for the applied ethicists in the Aristotelian tradition, reflecting on morally problematic consequences of her own philosophical discipline is perfectly compatible with the basic tenets of her moral philosophy.

Rawls's theory of justice. Rawls's book A Theory of Justice is a complex elaboration of criteria to determine whether a society is basically just (Rawls, 1971). From a Rawlsian point of view, a society is just if it is regulated by basic principles that were chosen by rational parties in an initial position of fairness. In this original position, the parties are under a veil of ignorance, which means that they know nothing about their personal particularities. They know nothing about their position in their society and nothing about their specific skills and preferences; they even do not know how developed their society will be and which generation they will be a part of. According to Rawls, principles that can be agreed upon by rational parties under this situation of fairness are just.

In order to decide which justice principles to accept, the parties have to take into account the principles of normative decision theory. Of more importance for the points of this paper, however, is the fact that the parties have to consider psychological expert knowledge, too. According to Rawls, this knowledge helps them to determine which principles will generate the most stable society: 'The general facts of human psychology and the principles of moral learning are relevant matters for the parties to examine. If a conception of justice is unlikely to generate its own support, or lacks stability, this fact must not be overlooked.' (Rawls, 1971, 145) Rawls emphasizes that it would be a striking argument against the adoption of certain principles if one showed that, from a psychological point, a society based on these principles would very likely be unstable:

It is for example, a consideration against a conception of justice that, in view of the laws of moral psychology, men would not acquire a desire to act upon it even when the institutions of their society satisfied it. For in this case there would be difficulty in securing the stability of social cooperation. It is an important feature of a conception of justice that it should generate its own support. (Rawls, 1971, 137-38)

For Rawls, principles of justice should only be adopted if it seems very likely that their implementation will not backfire and lead to an unstable society. Rawls devotes nearly the complete eighth chapter of $A$ Theory of Justice to developing a complex theory of moral learning, in order to show that his own justice principles will generate a more stable society than utilitarian principles.

It is not necessary to go further into the details of Rawls's complex argumentation. The important point should be obvious by now: Thinking about the consequences of 
implementing his own justice principles in a society was of high importance for Rawls. He was convinced that his justice principles would generate a more stable just society than utilitarian alternatives and that this fact is a strong argument for his principles. Therefore, reflecting on the consequences of ethical theory lies at the core of Rawls's theory. Moral philosophers that deploy Rawlsian arguments in debates of applied ethics have sound reasons to take seriously the morally problematic consequences of their communication.

Deontological ethics. Deontological theories strictly deny that actions can be justified by their consequences. For deontologists, ethical actions have to be in accordance with moral duties. This means that dutiful acts are of intrinsic moral worth regardless of their real-world impact. Immanuel Kant, the most famous deontologist, argued that moral philosophy should be based solely on a priori arguments. He repeatedly claims in several of his books on ethical theory (Groundwork of the Metaphysics of Morals, Critique of Practical Reason, The Metaphysics of Morals) that empirical arguments should play no role in ethical theory (Kant, 1965/1785, 1990/1797, 1998/1797, 2003/1787). For Kant, the consequences of an action have no bearing on its moral value. Therefore, it seems plausible that a rigorous Kantian will not be worried about the consequences of their own morally loaded communication. Applied ethicists working in the Kantian tradition might argue that their only job is to determine the rightness or wrongness of certain actions by a priori reasoning. If Kantian ethicists are convinced that consequences do not matter from an ethical standpoint, they might also be convinced that the consequences of deontological ethics itself are of no moral concern. For the Kantian deontologist, the sole fact that they have determined a certain action to be morally wrong is enough reason to justify open criticism of the people acting this way. Worries about the morally problematic consequences of this criticism are of no relevance for a radically aconsequentialist Kantian.

Of course, there are alternatives to Kantian deontological theories and not all deontologists might be as rigid as Kant was. Perhaps some deontological theories can provide reasons for reflecting on the moral consequences of moral theory. At least, it seems plausible that if one believes in absolute moral duties in general, one does not automatically have to believe in an absolute duty to communicate those moral duties under all circumstances (Birnbacher, 1999, 2016).

\section{Where to Go?}

The outlined discussion points to one important conclusion: Applied ethics should become even more interdisciplinary. Researchers have already made considerable efforts to bring applied ethics closer together with empirical sciences (e.g., Birnbacher, 1999, 2016; Ives et al., 2017; Chan, 2005; Frohlich \& Oppenheimer, 1992; van Thiel \& van Delden, 2010). This paper provides additional arguments to go further in that direction.

The main reason for this is that unethical consequences of morally loaded communication are a problem area where normative and empirical questions are closely intertwined. If an applied ethicist wants to evaluate the moral value of the consequences of her morally loaded communication, she has to know what exactly the consequences might be. She also has to know the likelihood of different possible scenarios. This raises many intricate empirical questions about the social impact of ethical criticism that can only be answered by drawing on expertise from different disciplines, such as psychology, sociology, political science, economic sciences, etc. Furthermore, depending on the special field the applied ethicist works in (e.g., medical ethics, animal ethics, business ethics, environmental ethics, 
etc.), different empirical disciplines and empirical results can be relevant for her. Accordingly, the applied ethicist might easily be confronted with an unmanageable amount of questions and potentially helpful research literatures. Therefore, the different normative and empirical questions raised by consequences of morally loaded communication can only be answered if experts from different fields and disciplines work closely together.

Another reason for interdisciplinary collaboration is the possibility that incorporating empirical knowledge might help applied ethicists in mitigating morally problematic consequences of their work. For example, applied ethicists could collaborate with psychologists and communication experts to develop strategies that can help improving the communication of their arguments to society. As illustrated by the huge literature on framing effects, communicating the exact same facts in semantically different ways can influence the way people evaluate these facts (Best \& Charness, 2015; Kühberger, 1998; Piñon \& Gambara, 2005; Steiger \& Kühberger, 2018). Consequently, it is plausible that the way ethical criticism is voiced can have an impact on people's reaction to that criticism. Exploring the most effective way of criticizing social practice from an ethical perspective without risking unethical backlashes can help in increasing the positive societal impact of applied ethics.

\section{Communicating Ethics}

The psychological literature I drew on above already points to several strategies of communication that can be used by applied ethicists in order to make their morally loaded communication more effective. Admittedly, none of these strategies will work perfectly under all circumstances. Nevertheless, they are useful heuristics and a good starting point for further investigations.

Be sympathetic: Always keep in mind that people are not simply evaluating ethical arguments in a rational and detached manner. They are fighting for their basic identities and simultaneously often do not realize that their argumentation is driven by their motivation of worldview defence. Therefore, the more you show understanding for their point of view, the more they will be willing to listen to you. An empathic and genuinely interested conversation about the individual background of a person and her reasons for taking certain ethical stances can sometimes achieve more than a listing of carefully thought out arguments. Consequently, do not overwhelm people with philosophical arguments. Especially in situations when your opponent gets very emotional during the dispute it might be better not to react with more counterarguments and rational analyses. Instead, ask the person why she is so aroused and emphasize that it is not your intention to make her uncomfortable. Try to understand her point of view and search for connecting factors for your ethical criticism. Perhaps you can cite insightful concrete case examples to which the person might relate to in order to make your ethical point.

Avoid devaluation: Probably the worst thing that can happen is that people get the feeling of being devaluated. If your opponent gets the impression that she appears as a bad or unintelligent person in light of your arguments, you will certainly fail in trying to convince her. Avoid any mode of expression that can be interpreted as ridicule, devaluation, arrogance, or condescension. In doing so, always try to adopt the perspective of your opponent. It is not important that you evaluate your statements as objective and down-to-earth; it is decisive that your opponent has the same impression.

Try to connect with people's worldview: Frame your ethical points in a way that fits into people's background beliefs. For example, justifying a moral obligation to avoid eating 
meat by pointing to the suffering of defenceless animals might not resonate well with a man that defines himself as a masculine, strong, and tough person. Emphasizing the benefits of vegetarian meals for his health, sportiness, and for his participation in a modern and trendy lifestyle might be more compatible with his self-image.

Be consistent as a person: Always practice what you preach. Of course, from the point of argumentation theory, the soundness of your arguments is completely independent of your personal behaviour. However, criticising people for emitting greenhouse gases and thereby destroying global climate while simultaneously flying around the globe yourself will make you untrustworthy in the eyes of your opponent. Accusations such as 'You do not comply with your ethical demands yourself' can be very powerful in drawing people's attention away from the content of your philosophical arguments. Being a role model by living up to your ethical standards without becoming a mirthless moralist will leave a stronger impression on some people than rational argumentation.

\section{Conclusion}

This paper has pointed out that applied ethics can itself be morally problematic, because it can lead or contribute to unethical consequences, such as serious psychological discomfort, moral backfiring, and hostile conflict. This should not discourage applied ethicists from doing their work or from criticizing morally questionable social circumstances. However, it should make them aware of the ethical dimension of their own morally loaded communication. It is important for moral philosophers to reflect upon the ethics of applied ethics. Beyond that, exploring the consequences of morally loaded communication and developing strategies for mitigating these consequences can be an excellent opportunity for interdisciplinary collaboration. More research is needed to work out the details of such interdisciplinary programs. Finally, in this article, it was not possible to investigate every ethical theory that is prominent in applied ethics. Consequently, future research could build on my arguments by providing more in-depth analyses of various theories in applied ethics and their approach to the morally problematic consequences of morally loaded communication.

Acknowledgments I would like to thank Stefan Röttig, Manuel Klein, and two anonymous reviewers for helpful comments on an earlier draft of this paper.

Funding Open Access funding enabled and organized by Projekt DEAL. Parts of the research where made possible by a scholarship of Studienstiftung des deutschen Volkes.

\section{Declarations}

Conflicts of Interest I have no conflicts of interest to disclose.

Open Access This article is licensed under a Creative Commons Attribution 4.0 International License, which permits use, sharing, adaptation, distribution and reproduction in any medium or format, as long as you give appropriate credit to the original author(s) and the source, provide a link to the Creative Commons licence, and indicate if changes were made. The images or other third party material in this article are included in the article's Creative Commons licence, unless indicated otherwise in a credit line to the material. If material is not included in the article's Creative Commons licence and your intended use is not permitted by statutory regulation or exceeds the permitted use, you will need to obtain permission directly from the copyright holder. To view a copy of this licence, visit http://creativecommons.org/licenses/by/4.0/. 


\section{References}

Aberson, C. L. (2019). Indirect Effects of Threat on the Contact-Prejudice Relationship. Soc Psych, 50(2), 105-126. https://doi.org/10.1027/1864-9335/a000364

Aberson, C. L., Healy, M., \& Romero, V. (2000). Ingroup Bias and Self-Esteem: A Meta-Analysis. Personality and Social Psychology Review, 4(2), 157-173. https://doi.org/10.1207/S15327957PSPR0402_04

Andsager, J. L., \& H. A. White. (2013). Self Versus Others: Media, Messages, and the Third-Person Effect. London u. New York: Routledge.

Aristotle. (2009). The Nicomachean Ethics: Translated by David Ross. Revised with an Introduction and Notes by Lesley Brown. Oxford et al. Oxford University Press.

Balliet, D., Wu, J., \& de Dreu, C. K. W. (2014). Ingroup Favoritism in Cooperation: A Meta-Analysis. Psychological Bulletin, 140(6), 1556-1581. https://doi.org/10.1037/a0037737

Bastian, B., \& Loughnan, S. (2017). Resolving the Meat-Paradox: A Motivational Account of Morally Troublesome Behavior and Its Maintenance. Personality and Social Psychology Review, 21(3), 278-299. https://doi.org/10.1177/1088868316647562

Bastian, B., Loughnan, S., Haslam, N., \& Radke, H. R. M. (2012). Don't Mind Meat? The Denial of Mind to Animals Used for Human Consumption. Personality and Social Psychology Bulletin, 38(2), 247-256. https://doi.org/10.1177/0146167211424291

Batson, C. D. (2016). What's Wrong with Morality? A Social-Psychological Perspective. Oxford University Press.

Best, R., \& Charness, N. (2015). Age Differences in the Effect of Framing on Risky Choice: A Meta-Analysis. Psychology and Aging, 30(3), 688-698. https://doi.org/10.1037/a0039447

Bettencourt, B. A., Dorr, N., Charlton, K., \& Hume, D. L. (2001). Status Differences and in-Group Bias: A Meta-Analytic Examination of the Effects of Status Stability, Status Legitimacy, and Group Permeability. Psychological Bulletin, 127(4), 520-542. https://doi.org/10.1037/0033-2909.127.4.520

Bilewicz, M., Imhoff, R., \& Drogosz, M. (2011). The Humanity of What We Eat: Conceptions of Human Uniqueness Among Vegetarians and Omnivores. European Journal of Social Psychology, 41(2), 201209. https://doi.org/10.1002/ejsp.766

Birnbacher, D. (1999). Ethics and Social Science: Which Kind of Co-Operation? Ethical Theory and Moral Practice, 2(4), 319-336.

Birnbacher, D. (2016). Where and When Ethics Needs Empirical Facts. In C. Brand (Ed.), Dual Process Theories in Moral Psychology: Interdisciplinary Approaches to Theoretical, Empirical and Practical Considerations. (pp. 41-55). Springer.

Bratanova, B., Loughnan, S., \& Bastian, B. (2011). The Effect of Categorization as Food on the Perceived Moral Standing of Animals. Appetite, 57(1), 193-196. https://doi.org/10.1016/j.appet.2011.04.020

Brown, J. D. (2012). Understanding the Better Than Average Effect: Motives (Still) Matter. Personality and Social Psychology Bulletin, 38(2), 209-219. https://doi.org/10.1177/0146167211432763

Buhl, T. (1999). Positive-Negative Asymmetry in Social Discrimination: Metaanalytical Evidence. Group Processes \& Intergroup Relations, 2(1), 51-58. https://doi.org/10.1177/1368430299021004

Campbell, W. K., \& Sedikides, C. (1999). Self-Threat Magnifies the Self-Serving Bias: A Meta-Analytic Integration. Review of General Psychology, 3(1), 23-43. https://doi.org/10.1037/1089-2680.3.1.23

Chan, H. M. (2005). Rawls' Theory of Justice: A Naturalistic Evaluation. Journal of Medicine and Philosophy, 30(5), 449-465. https://doi.org/10.1080/03605310500253022

Chapman, D. A., \& Lickel, B. (2016). Climate Change and Disasters: How Framing Affects Justifications for Giving or Withholding Aid to Disaster Victims. Soc Psychol Personal Sci, 7(1), 13-20. https://doi. org/10.1177/1948550615590448

Cooper, J. (2007). Cognitive Dissonance: Fifty Years of a Classic Theory. SAGE Publications.

Ditto, P. H., Liu, B. S., Clark, C. J., Wojcik, S. P., Chen, E. E., Grady, R. H., Celniker, J. B., \& Zinger, J. F. (2019). At Least Bias Is Bipartisan: A Meta-Analytic Comparison of Partisan Bias in Liberals and Cconservatives. Perspectives on Psychological Science, 14(2), 273-291. https://doi.org/10.1177/ 1745691617746796

Dunning, D., Heath, C., \& Suls, J. M. (2004). Flawed Self-Assessment: Implications for Health, Education, and the Workplace. The Journal of Abnormal and Social Psychology, 5(3), 69-106. https://doi.org/10. 1111/j.1529-1006.2004.00018.x

Eisend, M. (2017). The Third-Person Effect in Advertising: A Meta-Analysis. Journal of Advertising, 46(3), 377-394. https://doi.org/10.1080/00913367.2017.1292481

Festinger, L. (1957). A Theory of Cognitive Dissonance. Stanford University Press.

Frohlich, N., \& Oppenheimer, J. A. (1992). Choosing Justice: An Experimental Approach to Ethical Theory. University of California Press. 
Gaertner, L., Sedikides, C., Vevea, J. L., \& Iuzzini, J. (2002). The "I", the "We", and the "When": A MetaAnalysis of Motivational Primacy in Self-Definition. Journal of Personality and Social Psychology, 83(3), 574-591. https://doi.org/10.1037/0022-3514.83.3.574

Greitemeyer, T. (2014). I Am Right, You Are Wrong: How Biased Assimilation Increases the Perceived Gap Between Believers and Skeptics of Violent Video Game Effects. PLoS One, 9(14), 1-7.

Hart, P. S., \& Nisbet, E. C. (2012). Boomerang Effects in Science Communication: How Motivated Reasoning and Identity Cues Amplify Opinion Polarization About Climate Mitigation Policies. Communic Res, 39(6), 701-723. https://doi.org/10.1177/0093650211416646

Heine, S. J., \& Hamamura, T. (2007). In Search of East Asian Self-Enhancement. Personality and Social Psychology Review, 11(1), 1-24. https://doi.org/10.1177/1088868306294587

Hennes, E. P., Ruisch, B. C., Feygina, I., Monteiro, C. A., \& Jost, J. T. (2016). Motivated Recall in the Service of the Economic System: The Case of Anthropogenic Climate Change. Journal of Experimental Psychology: General, 145(6), 755-771. https://doi.org/10.1037/xge0000148

Hornsey, M. J., \& Fielding, K. S. (2017). Attitude Roots and Jiu Jitsu Persuasion: Understanding and Overcoming the Motivated Rejection of Science. American Psychologist, 72(5), 459-473. https://doi.org/ 10.1037/a0040437

Ives, J., Dunn, M., \& Cribb, A. (Eds.). (2017). Empirical Bioethics: Theoretical and Practical Perspectives. Cambridge University Press.

Jang, S. M., \& Kim, J. K. (2018). Third Person Effects of Fake News: Fake News Regulation and Media Literacy Interventions. Comput Human Behav, 80, 295-302. https://doi.org/10.1016/j.chb.2017.11.034

Kahan, D. M., Braman, D., Slovic, P., Gastil, J., \& Cohen, G. (2009). Cultural Cognition of the Risks and Benefits of Nanotechnology. Nature Nanotechnology, 4(2), 87-91. https://doi.org/10.1038/nnano.2008. 341

Kahan, D. M., Jenkins-Smith, H., \& Braman, D. (2011). Cultural Cognition of Scientific Consensus. Journal of Risk Research, 14(2), 147-174. https://doi.org/10.1080/13669877.2010.511246

Kant, I. 1965/1785. Grundlegung Zur Metaphysik Der Sitten [Groundwork of the Metaphysics of Morals]. 3.th ed. Hamburg: Meiner. Herausgegeben von Karl Vorländer.

Kant, I. 1990/1797. Metaphysische Anfangsgründe Der Tugendlehre: Metaphysik Der Sitten, Zweiter Teil [The Metaphysics of Morals, Part Two]. Hamburg: Meiner. Herausgegeben von Bernd Ludwig.

Kant, I. 1998/1797. Metaphysische Anfangsgründe Der Rechtslehre: Metaphysik Der Sitten, Erster Teil [The Metaphysics of Morals, Part One]. 2.th ed. Hamburg: Meiner. Herausgegeben von Bernd Ludwig.

Kant, I. 2003/1787. Kritik Der Praktischen Vernunft [Critique of Practical Reason]. Hamburg: Meiner. Herausgegeben von Horst Brandt u. Heiner Klemme.

Kühberger, A. (1998). The Influence of Framing on Risky Decisions: A Meta-Analysis. Organizational Behavior and Human Decision Processes, 75(1), 23-33. https://doi.org/10.1006/obhd.1998.2781

Kunda, Z. (1990). The Case for Motivated Reasoning. Psychological Bulletin, 108(3), 480-498. https://doi. org/10.1037/0033-2909.108.3.480

Lewandowsky, S., Mann, M. E., Brown, N. J. L., \& Friedman, H. (2016). Science and the Public: Debate, Denial, and Skepticism. J. Soc. Polit. Psych., 4(2), 537-553. https://doi.org/10.5964/jspp.v4i2.604

Lord, C. G., Ross, L., \& Lepper, M. R. (1979). Biased Assimilation and Attitude Polarization: The Effects of Prior Theories on Subsequently Considered Evidence. Journal of Personality and Social Psychology, 37(11), 2098-2109. https://doi.org/10.1037/0022-3514.37.11.2098

Loughnan, S., Bastian, B., \& Haslam, N. (2014). The Psychology of Eating Animals. Current Directions in Psychological Science, 23(2), 104-108. https://doi.org/10.1177/0963721414525781

Loughnan, S., Haslam, N., \& Bastian, B. (2010). The Role of Meat Consumption in the Denial of Moral Status and Mind to Meat Animals. Appetite, 55(1), 156-159. https://doi.org/10.1016/j.appet.2010.05. 043

Luhmann, N. (2008). Die Moral Der Gesellschaft [The Morals of Society]: Herausgegeben Von Detlef Horster. Frankfurt a.M.

Mezulis, A. H., Abramson, L. Y., Hyde, J. S., \& Hankin, B. L. (2004). Is There a Universal Positivity Bias in Attributions? A Meta-Analytic Review of Individual, Developmental, and Cultural Differences in the Self-Serving Attributional Bias. Psychological Bulletin, 130(5), 711-747. https://doi.org/10.1037/ 0033-2909.130.5.711

Mill, J. S. 1998/1871. Utilitarianism. Oxford et al. Oxford University Press. Editor: Crisp, R.

Mullen, B., Brown, R., \& Smith, C. (1992). Lngroup Bias as a Function of Salience, Relevance, and Status: An Integration. European Journal of Social Psychology, 22(2), 103-122. https://doi.org/10.1002/ejsp. 2420220202

Nauroth, P., Gollwitzer, M., Bender, J., \& Rothmund, T. (2014). Gamers Against Science: The Case of the Violent Video Games Debate. European Journal of Social Psychology, 44(2), 104-116. https://doi.org/ 10.1002/ejsp. 1998 
Nauroth, P., Gollwitzer, M., Bender, J., \& Rothmund, T. (2015). Social Identity Threat Motivates ScienceDiscrediting Online Comments. PLoS One, 10(2), 1-26.

Nickerson, R. S. (1998). Confirmation Bias: A Ubiquitous Phenomenon in Many Guises. Review of General Psychology, 2(2), 175-220. https://doi.org/10.1037/1089-2680.2.2.175

Nyhan, B., Reifler, J., Richey, J., \& Freed, G. L. (2014). Effective Messages in Vaccine Promotion: A Randomized Trial. Pediatrics, 133(4), 1-8. https://doi.org/10.1542/peds.2013-2365

Paul, N., Salwen, M. B., \& Dupagne, M. (2000). The Third-Person Effect: A Meta-Analysis of the Perceptual Hypothesis. Mass Communication and Society, 3(1), 57-85. https://doi.org/10.1207/ S15327825MCS0301_04

Piazza, J., Ruby, M. B., Loughnan, S., Luong, M., Kulik, J., Watkins, H. M., \& Seigerman, M. (2015). Rationalizing Meat Consumption. The 4Ns. Appetite, 91, 114-128. https://doi.org/10.1016/j.appet. 2015.04.011

Piñon, A., \& Gambara, H. (2005). A Meta-Analytic Review of Framming Effect: Risky, Attribute and Goal Framing. Psicothema, 17(2), 325-331.

Plous, S. (1993). Psychological Mechanisms in the Human Use of Animals. Journal of Social Issues, 49(1), 11-52. https://doi.org/10.1111/j.1540-4560.1993.tb00907.x

Pronin, E., Gilovich, T., \& Ross, L. (2004). Objectivity in the Eye of the Beholder: Divergent Perceptions of Bias in Self Versus Others. Psychological Review, 111(3), 781-799. https://doi.org/10. 1037/0033-295X.111.3.781

Rawls, J. (1971). A Theory of Justice. Cambridge u. Harvard University Press.

Riek, B. M., Mania, E. W., \& Gaertner, S. L. (2006). Intergroup Threat and Outgroup Attitudes: A MetaAnalytic Review. Personality and Social Psychology Review, 10(4), 336-353. https://doi.org/10. 1207/s15327957pspr1004_4

Rosenthal, S., Detenber, B. H., \& Rojas, H. (2018). Efficacy Beliefs in Third-Person Effects. Communic Res, 45(4), 554-576. https://doi.org/10.1177/0093650215570657

Rothgerber, H. (2013). Real Men Don't Eat (Vegetable) Quiche: Masculinity and the Justification of Meat Consumption. Psychol Men Masc, 14(4), 363-375. https://doi.org/10.1037/a0030379

Rothgerber, H. (2014). Efforts to Overcome Vegetarian-Induced Dissonance Among Meat Eaters. Appetite, 79, 32-41. https://doi.org/10.1016/j.appet.2014.04.003

Rubin, M., \& Hewstone, M. (1998). Social Identity Theory's Self-Esteem Hypothesis: A Review and Some Suggestions for Clarification. Personality and Social Psychology Review, 2(1), 40-62. https:// doi.org/10.1207/s15327957pspr0201_3

Ruby, M. B., \& Heine, S. J. (2012). Too Close to Home. Factors Predicting Meat Avoidance. Appetite, 59(1), 47-52. https://doi.org/10.1016/j.appet.2012.03.020

Sedikides, C., Gaertner, L., \& Vevea, J. L. (2005). Pancultural Self-Enhancement Reloaded: A MetaAnalytic Reply to Heine. Journal of Personality and Social Psychology, 89(4), 539-551. https:// doi.org/10.1037/0022-3514.89.4.539

Shao, W., \& Goidel, K. (2016). Seeing Is Believing? An Examination of Perceptions of Local Weather Conditions and Climate Change Among Residents in the U.S. Gulf Coast. Risk Analysis, 36(11), 2136-2157. https://doi.org/10.1111/risa.12571

Shen, L., Palmer, J., Kollar, L. M. M., \& Comer, S. (2015). A Social Comparison Explanation for the ThirdPerson Perception. Communic Res, 42(2), 260-280. https://doi.org/10.1177/0093650212467644

Singer, P. (1993). Practical Ethics. (2nd ed.). Cambridge University Press.

Singer, P. (2009). Animal Liberation: The Definitive Classic of the Animal Movement. Harper Collins.

Singer, P. (2011). Practical Ethics. (3rd ed.). Cambridge University Press.

Smith, E.R, D.M. Mackie, and H.M. Claypool. 2015. Social Psychology. 4th ed. New York u. London: Psychology Press.

Sowislo, J. F., \& Orth, U. (2013). Does Low Self-Esteem Predict Depression and Anxiety? A Meta-Analysis of Longitudinal Studies. Psychological Bulletin, 139(1), 213-240. https://doi.org/10.1037/a0028931

Stark, E., \& Sachau, D. (2016). Lake Wobegon's Guns: Overestimating Our Gun-Related Competences. Journal of Social and Political Psychology, 4(1), 8-23. https://doi.org/10.5964/jspp.v4i1.464

Steiger, A., \& Kühberger, A. (2018). A Meta-Analytic Re-Appraisal of the Framing Effect. Z Psychol, 226(1), 45-55. https://doi.org/10.1027/2151-2604/a000321

Sun, Y., Pan, Z., \& Shen, L. (2008). Understanding the Third-Person Perception: Evidence from a MetaAnalysis. The Journal of Communication, 58(2), 280-300. https://doi.org/10.1111/j.1460-2466. 2008.00385.x

Svenson, O. (1981). Are We All Less Risky and More Skillful Than Our Fellow Drivers? Acta Pathologica, Microbiologica, et Immunologica Scandinavica, 47(2), 143-148. https://doi.org/10.1016/ 0001-6918(81)90005-6 
Thürmer, J. L., \& McCrea, S. M. (2018). Beyond Motivated Reasoning: Hostile Reactions to Critical Comments from the Outgroup. Motiv Sci, 4(4), 333-346. https://doi.org/10.1037/mot0000097

Timm, S. C. (2016). Moral Intuition or Moral Disengagement? Cognitive Science Weighs in on the Animal Ethics Debate. Neuroethics, 9(3), 225-234. https://doi.org/10.1007/s12152-016-9271-x

van Thiel, G. J., \& van Delden, J. J. (2010). Reflective Equilibrium as a Normative Empirical Model. Ethical Perspect, 17(2), 183-202. https://doi.org/10.2143/EP.17.2.2049263

vanDellen, M. R., Campbell, W. K., Hoyle, R. H., \& Bradfield, E. K. (2011). Compensating, Resisting, and Breaking: A Meta-Analytic Examination of Reactions to Self-Esteem Threat. Personality and Social Psychology Review, 15(1), 51-74. https://doi.org/10.1177/1088868310372950

Xie, G., \& Johnson, J. M. Q. (2015). Examining the Third-Person Effect of Baseline Omission in Numerical Comparison: The Role of Consumer Persuasion Knowledge. Psychology and Marketing, 32(4), 438-449. https://doi.org/10.1002/mar.20790

Zell, E., Strickhouser, J. E., Sedikides, C., \& Alicke, M. D. (2020). The Better-Than-Average Effect in Comparative Self-Evaluation: A Comprehensive Review and Meta-Analysis. Psychological bulletin, 146(2), 118-149. https://doi.org/10.1037/bul0000218

Publisher's Note Springer Nature remains neutral with regard to jurisdictional claims in published maps and institutional affiliations. 